\title{
AGNIESZKA NĘCKA
}

(D) https://orcid.org/0000-0002-0874-0295

Uniwersytet Śląski w Katowicach

Katowice

\section{Podróżując w głąb człowieczego wnętrza. Na marginesie twórczości Olgi Tokarczuk}

Travelling into the inner human depths. Notes on Olga Tokarczuk's works

\begin{abstract}
The sketch focuses on two novels by Olga Tokarczuk (Flights and The Books of Jacob), seeking to show different ways of using the travel motif. In Tokarczuk's case, in fact, this is not only about moving in the geographical space, but also about exploring one's own self. The questions posed by the author of House of Day, House of Night are universal; addressing fundamental aspects, they reveal the $21^{\text {st }}$ century human condition. The writer often uses the motif of time, of the book or of travelling as such, showing literature as a specific language of communication that makes it possible to experience other people's lives.
\end{abstract}

Key words: Olga Tokarczuk, travel, identity, history

„Opisywanie jest jak używanie - niszczy; ścierają się kolory, kanty traca ostrość, w końcu to, co opisane, zaczyna blaknąć, zanikać. (...) Prawda jest straszna: opisać to zniszczyć" (Tokarczuk 2007, 79) - przekonywała w Biegunach Olga Tokarczuk. Ale, jak widać, potrzeba uchwycenia tego, co (nie)powtarzalne, dziw(acz)ne, ulotne czy wręcz przeciwnie - stabilne, jest silniejsza. Autorka E.E. tej pokusie ulega bowiem od ponad dwudziestu lat $i$, jak pokazuja przyznawane jej wielokrotnie prestiżowe nagrody czy wyróżnienia, na czele z tą najważniejszą - Nagrodą Nobla, umacnia swoją niezwykłą pozycję na rynku literackim ${ }^{1}$. Powiedzieć bo-

1 Twórczość Olgi Tokarczuk doczekała się zresztą licznych krytycznoliterackich komentarzy. Dość wspomnieć o zredagowanej przez Magdalenę Rabizo-Birek, Magdalenę Pocałuń-Dydycz i Adama Bieniasa monografię zbiorową zatytułowaną Światy Olgi Tokarczuk (Rze- 
wiem, że Olga Tokarczuk jest pisarką wyjątkową, to na dobrą sprawę niewiele powiedzieć. Jest wszakże swoistego rodzaju fenomenem. Uchodzi za wzorcową przedstawicielkę ,prozy środka” (Uniłowski 2006, 156196), potrafi uważnie wsłuchiwać się w oczekiwania czytelnicze i uwodzicielsko grać na wielu bębenkach. Podróżując w głąb człowieczego wnętrza, tworzy mityczne światy, w których łatwo się zatracić. Niezwykłe zdolności kreacjonistyczne, umiejętność konstruowania intrygujących opowieści połączone z żyłką psychologiczną sprawiaja, że proza Olgi Tokarczuk, łącząc żywioł fabularny i eseistyczny, z gracją balansuje między snuciem „lekkich i przyjemnych" narracji a niepokojąca egzystencjalno-filozoficzną problematyką. To proza urokliwa, dojrzała, gęsta i wieloznaczna, zmienna, a jednak już w jakimś sensie oswojona; tematyzująca sprawy uniwersalne, a mimo to niepozbawiona nacechowania indywidualnego. Na pytanie Michała Nogasia, co jest głównym tematem jej twórczości, Tokarczuk odpowiadała: „Prawdę mówiąc, od czasów Podró$\dot{y} y$ ludzi Ksiegi piszę stale o tym samym. O tym, co jest w stanie wzbudzić we mnie energię, pozwala stawiać ważne dla mnie pytania i w końcu daje przyjemność z pisania" (Tokarczuk 2019a, 52). Być może z tego między innymi powodu książki autorki Ostatnich historii (jeszcze zanim otrzymała Nagrodę Nobla) przełożono na ponad czterdzieści języków, umacniając tym samym jej pozycję nie tylko na polskim, ale i światowym rynku wydawniczym. Tokarczuk zresztą potrafi dość szybko zjednywać sympatię czytelników, bowiem pytania, jakie stawia, są uniwersalne; dotycząc kwestii fundamentalnych, odsłaniają kondycję człowieka XXI wieku. Pisarka, chętnie sięgając po motyw czasu, księgi czy podróżowania, pokazuje też, że literatura ,jest bardzo wyrafinowanym językiem komunikacji, który odwołuje się do współodczuwania i empatycznego porozumienia z drugim człowiekiem. Literatura bierze udział w cudzie, pozwala nam przeżywać życie innych ludzi" (Tokarczuk 2019b). A dzięki obserwowaniu innych można dowiedzieć się całkiem dużo o samym sobie. Wędrowanie/przemieszczanie się (po geograficznej przestrzeni, kulturach, czasie, obyczajach, lękach) znamienne jest dla większości utworów Tokarczuk, ale choćby dwa z nich w tym kontekście należy przywołać: szeroko komentowanych Biegunów i długo wyczekiwane Ksiegi Jakubowe.

szów 2013) czy Jake działać za pomocq stów? Proza Olgi Tokarczuk jako dyskurs krytyczny Katarzyny Kantner (Kraków 2019). Bogatą bibliografię dotyczącą twórczości autorki E.E. skompletowała Bernadetta Darska (zob. Darska 2014, 515-523). 


\section{Podróżować, aby żyć}

Określani na łamach „Tygodnika Powszechnego” przez Dariusza Nowackiego jako „dzieło totalne” (zob. Nowacki 2007), komplementowani w „Gazecie Wyborczej” przez Andrzeja Franaszka (zob. Franaszek 2007) Bieguni sa szeroko zakrojoną opowieścią starającą się uchwycić różnorodne aspekty podróżowania. Będąc - jak zauważył Arkadiusz Bagłajewski - „literackim patchworkiem, sylwiczną przeplatanką wrażeń, refleksji zogniskowanych wokół doświadczania świata w podróży i narracyjnych, nieraz rozbudowanych, fikcji odnoszonych do głównego tematu tej prozy: podróży jako stanu egzystencjalnego i sytuacji poznawczej w różnych czasach i miejscach" (Bagłajewski 2008, 159), opowiadają się za fragmentaryzmem, szkatułkowościa, nielinearnością i żerują nie tylko na doświadczeniach własnych, ale także na bogatych odsyłaczach intertekstualnych. Dzięki temu Biegunów można czytać na wiele (dopełniających się) sposobów: jako opowieść o „potrzebie uwalniania się od świata. Nie po to, by uciec, lecz by uniknąć pozoranctwa w życiu” (Poprawa 2007, 124), jako „liryczny traktat o roli mediów w życiu człowieka, z tą jednak niebywale ważną adnotacją, że on sam, człowiek, jest mechanizmem, maszynerią, konstrukcją składającą się z rozmaitych elementów, podzespołów, organów, urządzeń” (Larek 2008, 199), jako „powieść o utraconym dzieciństwie i poszukiwaniu dziecięctwa w sobie" (Darska 2007, 86) lub jako „współczesną przypowieść o człowieku” (Lenart 2010).

Wieloaspektowość tej prozy wynika między innymi z tego, że trudno byłoby streścić Biegunów. Mamy tu bowiem między innymi historie: Kunickiego, któremu na chorwackiej wyspie na trzy dni zginęła żona i dziecko, Annuszki, która uciekła z domu, porzucając męża i chorego syna, by stać się jedną ze współczesnych biegunek, szwedzkiego profesora i jego młodszej żony prowadzących prelekcje poświęcone kulturze antycznej na statku turystycznym pływającym po wyspach egejskich czy anatoma Filipa Verheyena, który pisał listy do swojej amputowanej nogi, a także fragmenty traktatu Psychologia podróżna, uwagi o miniaturyzacji kosmetyków podróżnych czy notatki aforystyczne. Owo „poszatkowanie” tkanki narracyjnej Biegunów autorka Domu džiennego, domu nocnego wyjaśnia w następujący sposób:

Stać z boku. Widzi się tylko świat we fragmentach, innego nie będzie. Sa momenty, okruchy, chwilowe konfiguracje, które raz zaistniawszy, rozpadają się na części. Życie? Niczego takiego nie ma; widzę linie, płaszczy- 
zny i bryły, i ich przemiany w czasie. Czas zaś wydaje się prostym narzędziem do mierzenia drobnych zmian, szkolną linijką z uproszczoną podziałką - to zaledwie trzy punkty: było, jest i będzie (Tokarczuk 2007, 204).

\section{Opowiadanie przypomina zatem układanie puzzli, dzięki czemu}

[p]rzerwane opowieści zostaja jednak dokończone, wiadomości z wykładów znajduja praktyczne zastosowanie. Narracją w Biegunach rządzi strategia opóźniania/odwlekania. Fragmentaryzacja sprzyja retardacjom, o czym świadcza porozrywane opowiadania, dodatkowo, budzi ciekawość i nie pozwala się zatrzymać, zmusza do ruchu. Opowieść staje się dosłownym ruchem, jest nie tylko następstwem słów i zdarzeń (Pekaniec 2008, 63-64).

Podszyci swoiście pojmowanym (zakamuflowanym pod postacia zmultiplikowanych masek) autobiografizmem Bieguni są jednakże ukierunkowani nie tyle na przemieszczanie się, ile na poznawanie Innych. Trudno się dziwić, skoro - co zostaje powiedziane w omawianej tu książce bodaj aż pięciokrotnie - „Celem mojej pielgrzymki jest zawsze inny pielgrzym”. Ale, jak na marginesie Biegunów konstatował Nowacki,

szlachetna intencja nie jest wyrazem naiwności, ma nawet zabarwienie ironiczne. Po pierwsze (...) węzłowymi stacjami tego pielgrzymowania są rozrzucone po świecie gabinety osobliwości i muzea historii medycyny. Owszem - Tokarczuk wyrusza na spotkanie z Innym, tyle że ów jest martwy, zredukowany do cielesnej powłoki lub rozczłonkowany w sensie dosłownym. Po wtóre - spotkania podróżniczki z innymi - żywymi pielgrzymami to $\mathrm{w}$ istocie spotkania z ekscentrykami. Tylko ci ostatni zasługują na opowieść (Nowacki 2007).

Chodzi zatem o swoiste kolekcjonowanie opowieści o innych, dzięki którym stałoby się możliwe dotarcie do własnego wnętrza. „Poznawanie siebie i poznawanie świata to w ujęciu pisarki procesy paralelne (...). Poznawanie siebie sprzęgnięte jest tu z poznawaniem Innego, a właściwie z klęską poznawczą. Nie moge poznać tajemnicy Innego, choć bliskiego" (Bagłajewski 2008, 160). Działania deszyfracyjne skazane są na niepowodzenie już choćby dlatego, że rzeczywistość jest wielowarstwowa, nieprzenikniona, rozpostarta między tym, co realne i alternatywne lub prawdopodobne. Nie wszystko da się w prosty i jednoznaczny sposób wytłumaczyć. Dzieje się tak między innymi dlatego, że „[r]óżne momenty czasu wiszą w przestrzeni jak przeście- 
radła, jak ekrany, na których wyświetla się jakiś moment; świat składa się z takich nieruchomych momentów, wielkich metazdjęć, a my przeskakujemy z jednego w drugi" (Tokarczuk 2007, 431). Chodzi zatem - najkrócej rzecz ujmując - o nieustanną konieczność bycia w ruchu. Wszystko, zostawszy podporządkowane zasadzie permanentnej płynności, składa się na wielopłaszczyznową rzeczywistość. Jak bowiem czytamy w Biegunach:

zdałam sobie sprawę, że - mimo wszelkich niebezpieczeństw - zawsze lepsze będzie to, co jest w ruchu, niż to, co w spoczynku; że szlachetniejsza będzie zmiana niż stałość; że znieruchomiałe musi ulec rozpadowi, degeneracji i obrócić się w perzynę, ruchome zaś - będzie trwało nawet wiecznie (Tokarczuk 2007, 8).

Ciąłe przemieszczanie się (rozumiane także jako postęp cywilizacyjno-technologiczny) ma umożliwiać ochronę przed szeroko definiowanym złem. Świat jest więzieniem, ludzie zaś są „zbudowani z obron, z tarcz i zbroi, jesteśmy miastami, których architektura sprowadza się do murów, baszt i fortyfikacji; państwami bunkrów" (Tokarczuk 2007, 17). Ale, jak zauważa Bagłajewski,

w finale utworu odsłania się wielki temat tej prozy - światy możliwe. Świat, światy ujęte są z perspektywy wyobraźni gnostyckiej i panteistycznej. Czy one się wzajemnie nie wykluczają? Otóż nie. Możemy nawet dostrzec, jak się supłaja, jak wymiennie przenikaja na powierzchnię zdarzeń i refleksji o zdarzeniach. Bo i na zamknięcie w świecie-więzieniu i takoż na panteistyczną płynność rzeczy spogląda się tu z góry - taką perspektywę przyjęła narratorka - a takie spojrzenie umożliwia subtelną ironię, dystans, ale też kiedy trzeba empatyczną bliskość z bytem (Bagłajewski 2008, 160).

W rezultacie przemieszania się dystansu i empatii możliwy jest zachwyt nad tym, co brzydkie, wadliwe, nieprzewidywalne. Narratorka prozy Tokarczuk mówi o tym wprost:

pociąga mnie wszystko, co popsute, niedoskonałe, ułomne, pęknięte. Interesują mnie formy byle jakie, pomyłki w dziele stworzenia, ślepe zaułki. To, co miało się rozwinąć, ale z jakichś względów pozostało niedorozwinięte; albo wręcz przeciwnie - przerosło plan. Wszystko, co odstaje od normy, co jest za małe albo za duże, wybujałe lub niepełne, monstrualne i odrażające. Formy, które nie pilnują symetrii, które się multiplikuja, 
przyrastaja po bokach, pączkuja, lub przeciwnie, redukują wielość do jedności. Nie interesują mnie wydarzenia powtarzalne (...) Moja wrażliwość jest teratologiczna, monstrofilarna. Mam nieustanne i męczące przekonanie, że właśnie tutaj prawdziwy byt przebija się na powierzchnię i ujawnia swoją naturę. Nagłe, przypadkowe odsłonięcie. Wstydliwe „ups”, rąbek bielizny spod starannie uplisowanej spódnicy (Tokarczuk 2007, 22-23).

Pociaga zatem to, co wymyka się schematom, stereotypom, konwenansom. Owo wstydliwe „ups” pozwala zbliżyć się do tajemnicy istnienia, a ta jak przekonuje Tokarczuk - ukryta jest na nietypowych szlakach podróżniczych. Trzeba więc podróżować, aby żyć i by o tym życiu opowiadać.

\section{Podróżować, aby odnaleźć wolność}

W Ksiegach Jakubowych, które starannie łączą fakty z konfabulacjami², Tokarczuk umieszcza akcję opowieści na Podolu w drugiej połowie XVIII stulecia, koncentrując się przede wszystkim na zapomnianym już dziś ruchu religijno-społeczno-politycznym frankistów. Na głównego bohatera powieści wybiera postać niejednoznaczną i kontrowersyjną - Jakuba Franka, charyzmatycznego, pełnego ambiwalencji człowieka, który chciał być uznawany za Mesjasza. Zdaniem jednych był człowiekiem ,niespokojnym i wewnętrznie wzburzonym, to nie jest mędrzec, ale rebeliant”" (Tokarczuk 2014, 693), uwodzącym kobiety „krnąbrnym rozrabiaka”, oszustem, przybłęda, którego należy traktować jak „konkurencję, jak kogoś, kto bezczelnie wystawił obok nich kram ze zbawieniem, taki sam jak ich, ale ceny dał lepsze" (Tokarczuk 2014, 682), wielbicielem kajmaku i tureckich słodyczy z sezamu i miodu. Jego zwolennicy z kolei uważali go za przystojnego, uczonego świętego, który się nie wywyższa i żyje skromnie. Jakakolwiek by nie była prawda, urodzony w rodzinie żydowskiej Jakub Frank, wyprowadzając „,swoich” z niewoli, starał się zapewnić im poczucie bezpieczeństwa i szacunek otoczenia. Dzięki

\footnotetext{
${ }^{2}$ Ksiegi Jakubowe są swoistym połączeniem zapisków z podróży, sztuki epistolarnej, dysput teologicznych i twórczości hagiograficznej. W konsekwencji snuta przez Tokarczuk dygresyjna opowieść rozpada się od wewnątrz. Różnorodność form jest - moim zdaniem - w tym wypadku wadac. Momentami odciąga uwagę od nadrzędnej problematyki. Trudna do zrekonstruowania wielowątkowość i mnogość bohaterów, którzy w trakcie opowieści zmieniaja imiona i nazwiska, sprawia ponadto, że nad narracją Tokarczuk nie sposób zapanować.
} 
niemu przestano ich pogardliwie nazywać „przechrztami” i pozwolono stworzyć swoiste państwo w państwie. Ale Tokarczuk powraca do historii, próbując odtworzyć losy frankistów głównie po to, by rozważać jedną z podstawowych kwestii: dlaczego człowiek, który jest pełen sprzeczności, potrafi pociągnać za sobą tłumy i przekonać je do walki w imię wyznawanych przez siebie wartości.

Tymi, którzy dali się uwieść Frankowi, kierowały różne powody. Byli to zatem ludzie, którzy poszukiwali tolerancji, bliskości drugiego człowieka i swojego miejsca w świecie, którzy pragnęli żyć godnie, którzy niewiele mieli do stracenia lub ci, którzy chcieli zerwać z monotonią życia lub wyzwolić się spod kontroli innych. Nic dziwnego, że bohaterem swojej opowieści Tokarczuk uczyniła właśnie Jakuba Franka. „Frank, frenk znaczy obcy. (...) to się podoba Jakubowi - być obcym to cecha tych, którzy często zmieniali miejsce zamieszkania" (Tokarczuk 2014, 732). Nowe miejsce wiązało się z budowaniem swego życia od nowa. Bycie obcym oferowało przeto swego rodzaju wolność.

O Franku mówią właściwie wszyscy, poza samym narratorem. Przemysław Czapliński zastosowanie takiej strategii przez Tokarczuk wyjaśnia następująco:

Lektura szybko uświadamia, dlaczego tak wieloznaczna postać doczekała się tak niewielu opracowań. Frank (...) należy do historii wszystkich państw Europy Środkowej XVIII w. - Polski, Rosji, Austrii, Niemiec - ale żadna z tych historii nie potrafi przetłumaczyć go na język wspólny. Należy do wszystkich po trochu i do nikogo w zupełności. Dlatego najważniejsza decyzja poznawcza przy pisaniu miała charakter kompozycyjny: Kto ma wyjaśnić tajemnicę Franka? Komu powierzyć słowa wiarygodne, a komu domysły? Powieściowa konstrukcja jest odpowiedzią najuczciwszą: o Franku mówią wszyscy z wyjątkiem narratora. Nikt też nie formułuje wyjaśnienia ostatecznego. Dzięki temu Frank pozostaje postacią historyczną i pełnowymiarowa, a zarazem - do końca niejasną. Rodzi się z tego napięcie między wielością opinii i niejednoznacznością bohatera, naocznością wydarzeń i niejasnością znaczeń. Za sprawą metody narracyjnej poznajemy świat w szczegółach i zarazem nie możemy do środka tego świata się przedostać (Czapliński 2014).

Efektem tego zabiegu jest to, że Frank pozostaje postacią nieuchwytna. Czerpiąc z judaizmu, sabataizmu, islamu i katolicyzmu, wywołuje rozłam i przekonuje, że reguły religii należy nieustannie modyfikować. Traktuje bo- 
wiem religię pragmatycznie, jako narzędzie służące osiagnięciu obranego celu. Jakub nade wszystko pragnął równości. To sprawiło, że idący jego śladem Żydzi poprzez przyjęcie chrztu chcieli odmienić swoją codzienność. Bo też i Rzeczypospolita Obojga Narodów 3 jawi się jako kraj, w którym dominuje przemoc i nierówność społeczna. Podzieleni na warstwy arystokraci, szlachta, mieszczaństwo i chłopi wzajemnie się nienawidzili. Zwłaszcza najniższa warstwa odczuwała skutki niewolnictwa. Powszechnie znane było zjawisko „biegunów” - zbiegłych od pana chłopów. Powodem rozwarstwienia i stosunków feudalnych nie był tylko status majątkowy. Katolicy nie byli w stanie porozumieć się z wyznawcami innych religii, zaś mężczyźni traktowali kobiety przedmiotowo. W najgorszym położeniu znajdowali się jednak deprecjonowani przez wszystkich Żydzi. Pozbawieni przywilejów i ochrony prawnej, wyzyskiwani, prześladowani marzyli o tak zwanej normalności.

Polska to kraj, gdzie wolność religijna i nienawiść religijna w równym się stopniu spotykają. Z jednej strony Żydzi mogą tu praktykować swoją religię, jak chca, mają swoje swobody i sądownictwo własne. $Z$ drugiej zaś nienawiść do nich jest tak wielka, że samo słowo » $\dot{Z} y d$ « jest w poniewierce i dobrzy chrześcijanie używaja go jako przekleństwa (Tokarczuk 2014, 527).

Trudno się przeto dziwić, że o swoje prawa walczyli za pomocą wchodzenia w różnorakie układy i niejednokrotnego zaprzedawania samych siebie. Herezja jawi się tu zatem nie tylko jako droga do poznania własnej wiary, ale także swojego ,ja”.

3 Jak zauważa Przemysław Czapliński: „Powieść Tokarczuk rewoltuje obraz życia religijnego w XVIII w., ale też odmienia postrzeganie Rzeczypospolitej Obojga Narodów. Rewizję swoja pisarka rozgrywa na rewersie Trylogii. Sienkiewicz, chcąc uzyskać obraz wyidealizowany, musiał przedstawić Polskę szlachecką z perspektywy szlacheckiej - podrzędna pozycja kobiet, dominacja jednego wyznania, okrutna hierarchia społeczna, dystrybucja bogactwa i biedy nabierały charakteru koniecznego. W Księgach Jakubowych konieczność znika, więc hierarchia odsłania się jako przemoc. U Sienkiewicza wojna wkraczająca do Polski jest zakłóceniem dobrego ładu. W powieści Tokarczuk, dziejącej się sto lat później, porządek społeczny pozostał bez zmian, ale jawi się on jako mieszanina bałaganu i przemocy w majestacie prawa" (Czapliński 2014). Na tę kwestię uwagę zwracała większość recenzentów. Dość przywołać Krystynę Pietrych, która zanotowała: „Tokarczuk - w tym widzę wielką wagę jej Księgi - demistyfikuje polskie zbiorowe fantazmaty szlacheckiej tolerancji i złotej wolności, każąc się nam zmierzyć z tym, co ze społecznej świadomości przez stulecia zostało wyparte, i w efekcie niemal całkowicie wyrugowane ze sfery wspólnotowych praktyk symbolicznych" (Pietrych 2015, 71). 
Dzieje frankistów do łatwych nie należały. Przywódca sekty początkowo (dzięki tureckiemu ubiorowi) budził ciekawość, która z czasem zamieniała się w obojętność, a potem we wrogość. Stąd z bywalca w kręgach bliskich warszawskiemu dworowi królewskiemu został przez władze kościelne oskarżony o herezję i skazany na dożywotni areszt w klasztorze na Jasnej Górze. Więzienie nie zmusiło go jednak do zaprzestania propagowania swoich nauk. Wieloletnia działalność Franka, rozpościerająca się między terenami południowej Polski, Czech, Austrii, Turcji, Rumunii i południowych Niemiec, przyniosła częściową asymilację i emancypację Żydów. Trudniący się głównie drobnym handlem kupcy i rzemieślnicy po przyjęciu chrztu, pnąc się po drabinie społecznej, wtapiali się w polskie społeczeństwo. $\mathrm{Na}$ dzieje tego ruchu wpływ miały zatem nie tylko osobiste przekonania Jakuba Franka, ale również szlaki handlowe, mesjanizm, kabała, polityczne ambicje polskiego duchowieństwa czy dyktowane własnymi interesami decyzje europejskich władców. W efekcie autorka Ostatnich historii nie wybiela przeszłości. Opisuje zarówno cierpienia zadawane wyznawcom Franka, jak i okrucieństwa, których dopuszczali się frankiści względem innych.

Przypominając jedną z kart z zamierzchłych czasów, Tokarczuk oddaje zatem głos tym, których historia zmarginalizowała, ponownie udowadniając, że ulegamy potrzebie idealizowania naszej przeszłości. Przekonuje ponadto, że wszystko zależy od punktu widzenia. Stąd wyraziście odmalowane zostały zwłaszcza portrety kobiece, wśród których na plan pierwszy wysunęły się między innymi: żydowska prorokini i gospodyni Chaia, kasztelanowa kamieniecka Katarzyna Kossakowska czy przelotna kochanka Jakuba - Gitla. Mimo trudnych okoliczności, będąc silnymi jednostkami, potrafiły one wziąć odpowiedzialność za swoje życie i uciec od wypełniania roli ofiar.

Snuta przez Tokarczuk narracja ma ambicje bycia opowieścią uniwersalną. W XVIII-wiecznej historii bez problemu da się dostrzec między innymi obnażanie znanego w każdej epoce mechanizmu sugestywności idei. Autorka Prawieku i innych czasón problematyzuje współczesne uleganie złudzeniom i fascynacjom. Przypomina również, że mechanizmy ludzkiego postępowania bez względu na czas historyczny i przestrzeń geograficzną nie ulegają zmianie. Pisarka pyta na przykład:

Czy to nie jest spoiwem ludzkiego świata? Czy po to są nam potrzebni inni ludzie, żeby nam dostarczyć radości, żeśmy od nich lepsi? O dziwo, nawet ci - wydawałoby się - najgorsi w swoim poniżeniu znajduja przewrotną satysfakcję, że nie ma już gorszych od nich, a więc właśnie w tym są górą (Tokarczuk 2014, 573). 
Trywializmem jest dziś stwierdzenie, że światem rządzą silniejsi, zaś stosunki feudalne stale naznaczają ludzkie relacje. Żadnym novum nie jest także konstatacja, zgodnie z którą ludzie są egoistami lubiącymi wiedzieć, że innym jest gorzej. A jednak mimo to niewiele się zmienia, nie wyciagamy wniosków z przeszłości, nieustannie popełniając te same błędy. Autorka Biegunów i tym razem przekonuje, że nierówność, niesprawiedliwość, poniżenie, przemoc należą do naturalnego biegu historii - tej od wieków spisywanej i tej z różnych powodów przemilczanej. Ważne jest, by dzięki pisaniu nadać porządek dziejącym się wydarzeniom. Wszak „[j]edni leczą ludzi, inni budują domy, jeszcze inni studiują księgi i przestawiają słowa, żeby znaleźć w nich właściwy sens" (Tokarczuk 2014, 822). Ksiegi Jakubowe tym samym dają się również czytać jako afirmacja literatury będącej skarbnicą wiedzy o przeszłości i o nas samych. W efekcie literatura - przypominająca mozaikę cudzej mowy (także tej opartej na źródłach historycznych) - staje się sposobem (auto)poznania. Pisarze nieustannie czerpia z tradycji, korzystają z tekstów innych autorów. Nie inaczej postępuje Olga Tokarczuk. Sięgając do źródeł, (re)konstruuje niejako rzeczywistość Polski z XVIII stulecia, ze szczególnym uwzględnieniem biografii Jakuba Franka, ale uzupełnia ją własnymi spostrzeżeniami i zniekształceniami. W rezultacie Ksiegi Jakubowe nie przynoszą ostatecznych rozstrzygnięć. Tokarczuk nie rozlicza, nie ocenia, nie opowiada się za żadną z tez. Nie odsłania tajemnicy dotyczącej tego, kim był Frank, choćby dlatego, że odkryć jej nie można. Pokazując Jakuba Franka jako człowieka charyzmatycznego, choć niedoskonałego, obnaża kondycję (nie tylko) XVIII-wiecznego społeczeństwa. Wszak potrzeba ulegania rozmaitym iluzjom znamienna jest również dla naszego „tu i teraz”. Dzieje się tak też dlatego, że historia lubi zataczać kręgi. Rolą literatury (jedną z wielu, rzecz jasna) jest przechowywanie w pamięci zdarzeń i wskazówek dla potomnych. Pisarz natomiast inspiracje czerpać powinien zewsząd. Olga Tokarczuk przyznała w rozmowie z Nogasiem:

U Phipipa K. Dicka znalazłam kiedyś piękną metaforę. Twierdził, że pisarze sa jak sroki. Grzebia po śmietnikach i wyciagaja z nich złotka oraz różne świecące przedmioty, by znosić je do swoich gniazd. Podoba mi się to porównanie. Czasem wydaje mi się, że jestem właśnie taką sroka. Latami zbieram rzeczy porzucone, choć nadal błyszczące, ale przez innych niezauważone i gdy przyjdzie odpowiedni czas, składam z nich powieści (Tokarczuk 2019a, 53). 
Noblistka daje innym szansę podróżowania nie tylko w głąb własnego „ja”, ale równiė̇ po życiu innych.

\section{Literatura}

Bagłajewski A., 2008, Bieguni, „Kresy”, nr 3.

Czapliński P., 2014, „Ksiegi Jakubowe”, czyli dwieście lat samotności, http://wyborcza.pl/1,7541 0,16835955,_Ksiegi_Jakubowe_czyli_dwiescie_lat_samotnosci.html [dostęp: 07.09.2016].

Darska B., 2007, To, co umożliwia przetrwanie, „Opcje”, nr 4.

Franaszek A., 2007, Wezwanie niepokoju, „Gazeta Wyborcza”, nr 242.

Kantner K., 2019, Jak dziatać za pomoca stów? Proza Olgi Tokarczuk jako dyskurs krytyczny, Kraków.

Larek M., 2008, Literatura i nowe media, „Czas Kultury”, nr 6.

Lenart I., 2010, „Bieguni” Olgi Tokarczuk jako wspótczesna praypowieśs o człowieku, w: Andres Z., Pasterski J., red., Inna literatura? Dwudziestolecie 1989-2009, t. 1, Rzeszów.

Nowacki D., 2007, Podróżowanie jest konieçnościq. Olga Tokarczuk - powrót do formy, „Tygodnik Powszechny", nr 41.

Pekaniec A., 2008, Opowiadać-podróżować- żyć, „Dekada Literacka”, nr 1.

Pietrych K., 2015, „Ksiegi Jakubowe”- powieść wspótczesna, „Nowe Książki”, nr 2.

Poprawa I., 2007, Olga travel, „Odra”, nr 12.

Rabizo-Birek M., Pocałuń-Dydycz M., Bienias A., red., 2013, Światy Olgi Tokarczuk, Rzeszów.

Tokarczuk O., 2007, Bieguni, Kraków.

Tokarczuk O., 2014, Ksiegi Jakubowe, Kraków.

Tokarczuk O., 2019a, Jestem sroka Olga, rozm. przepr. Nogaś M., „Książki. Magazyn do Czytania", nr 6.

Tokarczuk O., 2019b, Wszystko przemawia za tym, że literatura stanie sie jeszcze bardziej niszowa, rozm. przepr. Gruszczyński A., https://weekend.gazeta.pl/weekend/1,152121,24573774, olga-tokarczuk-wszystko-przemawia-za-tym-ze-literatura-stanie.html [dostęp: 28.01.2020].

Agnieszka Nęcka - dr hab., Instytut Literaturoznawstwa, Wydział Humanistyczny, Uniwersytet Śląski w Katowicach, Katowice, Polska.

Krytyk literacki, literaturoznawca, autorka książek: Granice przyzwoitości. Doświadczenie intymności w prozie najnowszej (2006); Starsze, nowsze, najnowsze. Szkice o prozie polskiej XX i XXI wieku (2010); Cielesne o(d)słony. Dyskursy erotyczne w polskiej prozie po 1989 roku (2011); Co ważne $i$ ważniejsze. Notatki o prozie polskiej XXI wieku (2012); Emigracje intymne. O współczesnych polskich narracjach autobiograficznych (2013); Polifonia. Literatura polska początku XXI wieku (2015). Redaktor działu krytyki literackiej w „Postscriptum Polonistycznym”. Stypendystka Marszałka Województwa Śląskiego w dziedzinie kultury (2009).

Kontakt: agnieszka.necka@us.edu.pl 